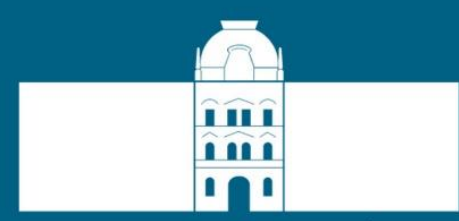

Univerza v Mariboru

\title{
Vloga in pomen tehniškega izobraževanja v OŠ: kdo bo poučeval tehniko leta $2020 ?$
}

\author{
Urednika: \\ dr. Mateja Ploj Virtič \\ dr. Kosta Dolenc
}




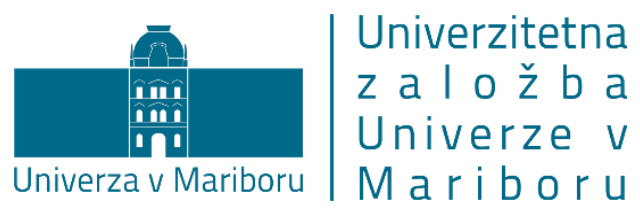




\section{(C) Univerzitetna založba Univerze v Mariboru}

Vse pravice pridržane. Brez pisnega dovoljenja založnika je prepovedano reproduciranje, distribuiranje, predelava ali druga uporaba tega dela ali njegovih delov v kakršnemkoli obsegu ali postopku, vključno $\mathrm{s}$ fotokopiranjem, tiskanjem ali shranjevanjem v elektronski obliki.

Naslov: Vloga in pomen tehniškega izobraževanja v OŠ: kdo bo poučeval tehniko leta 2020?

Avtorji: doc. dr. Mateja Ploj Virtič (Univerza v Mariboru, Fakulteta za naravoslovje in matematiko), doc. dr. Kosta Dolenc (Univerza v Mariboru, Fakulteta za naravoslovje in matematiko), prof. ddr. Boris Aberšek (Univerza v Mariboru, Fakulteta za naravoslovje in matematiko), izr. prof. Andrej Šorgo (Univerza v Mariboru, Fakulteta za naravoslovje in matematiko), izr. prof. Slavko Kocijančič (Univerza v Ljubljani, Pedagoška fakulteta).

Urednika: doc. dr. Mateja Ploj Virtič (Univerza v Mariboru, Fakulteta za naravoslovje in matematiko), doc. dr. Kosta Dolenc (Univerza v Mariboru, Fakulteta za naravoslovje in matematiko)

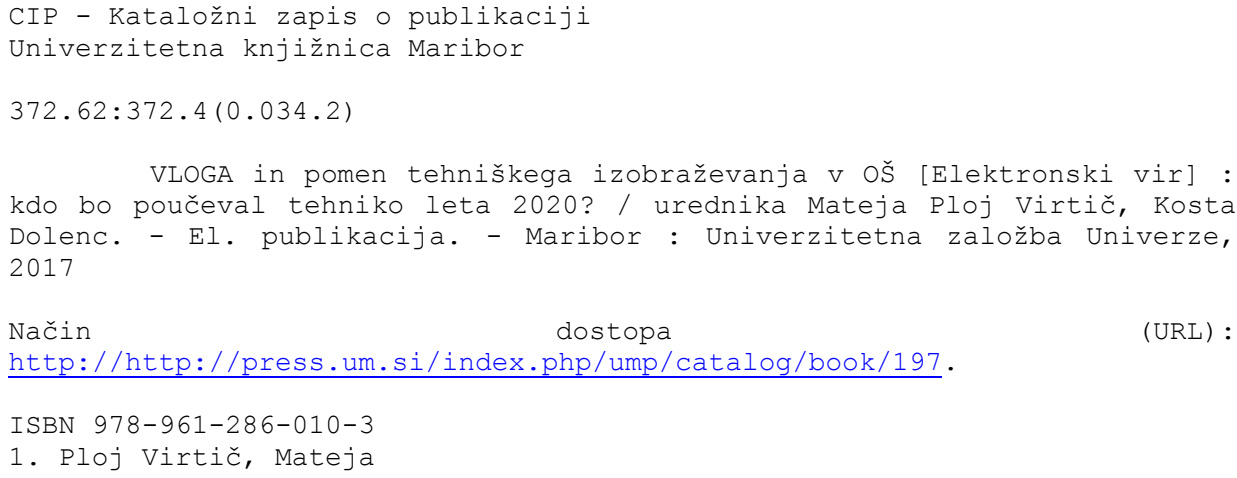

Založnik:

Univerzitetna založba Univerze v Mariboru Slomškov trg 15, 2000 Maribor, Slovenija tel. +386225042 42, faks +38622523245

http://press.um.si, zalozba@um.si

\section{Izdajateljica:}

Univerza v Mariboru, Fakulteta za naravoslovje in matematiko

Koroška cesta 160, 2000 Maribor, Slovenija tel. +386222938 44, faks +38622518180 http://www.fnm.um.si, dekanat.fnm@um.si

Leto izdaje: 2017

Cena: brezplačen izvod

Odgovorna oseba založnika:

prof. dr. Igor Tičar, rektor (Univerza v Mariboru) 



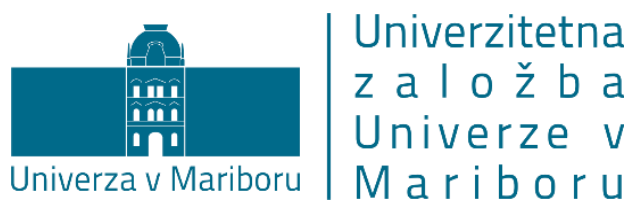

\title{
Vloga in pomen tehniškega izobraževanja v OŠ: kdo bo poučeval tehniko leta 2020 ?
}

\author{
Urednika: \\ dr. Mateja Ploj Virtič \\ dr. Kosta Dolenc
}

Februar 2017 



\title{
Vloga in pomen tehniškega izobraževanja v OŠ: kdo bo poučeval tehniko leta 2020 ?
}

\author{
MAteja Ploj ViRTič \& Kosta DOLEnC
}

Povzetek Ponosni smo lahko na rezultate mednarodnih raziskav (TIMSS, PISA), ki nas na področju izobraževanja naravoslovnih predmetov in matematike postavljajo v sam svetovni vrh ali vsaj blizu njega. Lahko pa se vprašamo: Kako dolgo še? Iz projekcij naraščanja števila otrok v generaciji, upokojevanja učiteljev naravoslovno-matematično-tehničnih predmetov (NARMATEH) ter števila tistih, ki v univerzitetnih programih za izobraževanje učiteljev teh ved tudi diplomirajo, lahko napovemo katastrofo - ustrezno izobraženih učiteljev NARMATEH že v nekaj letih ne bo dovolj, da bi nadomestili izpad. To utemeljujemo z védenjem, da se bo leta 2030 upokojilo 1236 danes zaposlenih učiteljev NARMATEH, od tega 265 učiteljev predmeta Tehnika in tehnologija (TIT) v osnovni šoli. Diplomantov, ki bi jih lahko nadomestili pa zaradi nezadostnega vpisa ne bo dovolj. Medtem, ko lahko univerzitetni učitelji in sodelavci $\mathrm{v}$ programih NARMATEH zagotovimo kakovost dela $\mathrm{z}$ vpisanimi, pa sami ne moremo zagotoviti vzpodbud ter materialnih pogojev, s katerimi bi lahko privabili in nato tudi izobrazili bodoče učitelje.

Ključne besede: tehniško izobraževanje • osnovna šola • NARMATEH • Slovenija

\footnotetext{
NASLOV UREDNIKOV: dr. Mateja Ploj Virtič, docentka, Univerza v Mariboru, Fakulteta za naravoslovje in matematiko, Koroška cesta 160, 2000 Maribor, Slovenija, e-pošta: mateja.plojvirtic@um.si. dr. Kosta Dolenc, docent, Univerza v Mariboru, Fakulteta za naravoslovje in matematiko, Koroška cesta 160, 2000 Maribor, Slovenija, e-pošta: kosta.dolenc@um.si.
}

DOI 10.18690/978-961-286-010-3 ISBN 978-961-286-010-3

(C) 2016 Univerzitetna založba Univerze v Mariboru

Dostopno na: http://press.um.si. 

VLOGA IN POMEN TEHNIŠKEGA IZOBRAŽEVANJA V OŠ: KDO BO POUČEVAL TEHNIKO LETA 2020?

M. Ploj Virtič \& K. Dolenc

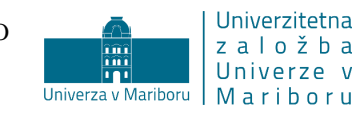

\section{Kazalo}

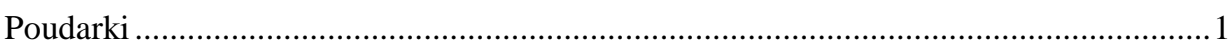

Pregled dosedanjih aktivnosti za reševanje problematike tehniškega izobraževanja ........3

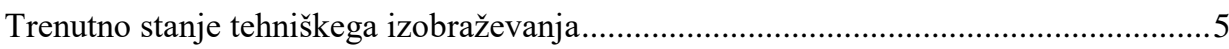

Problematika tehniškega izobraževanja danes ......................................................... 9

Predlagani ukrepi ............................................................................................ 13

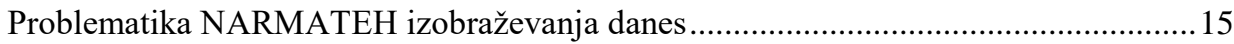

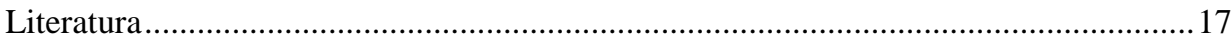

Priloga: Statistični podatki vpisa in diplomantov..................................................... 19 

VLOGA IN POMEN TEHNIŠKEGA IZOBRAŽEVANJA V OŠ: KDO BO POUČEVAL TEHNIKO LETA 2020?

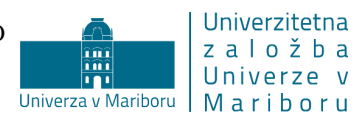

\section{Poudarki}

Kakovost izvedbe naravoslovno-matematično-tehniškega (NARMATEH) izobraževanja in še posebej predmeta Tehnika in tehnologija (TIT) v OŠ je ogrožena.

Ogroža jo pričakovano in napovedano pomanjkanje ustrezno izobraženih učiteljev NARMATEH.

- $\quad$ Sttevilo prvošolcev v OŠ zadnjih 8 let narašča.

- V naslednjih 13 letih (2017-2030) se bo upokojilo 1236 OŠ učiteljev NARMATEH, od tega kar 265 učiteljev TIT, (vir: Ministrstvo za izobraževanje, znanost in šport (MIZŠ)).

- Vpis in število diplomantov na študijskih programih pedagoške tehnike je od leta 2007 upadel za 70\%, skupno na pedagoških študijskih programih NARMATEH pa kar $60 \%$.

- V letu 2015 je diplomiralo le 11 študentov pedagoške tehnike in to število bo, glede na razpoložljive podatke o vpisu, v prihodnje še manjše.

- S trenutnim številom diplomantov Univerz v Mariboru (UM) in Ljubljani (UL) lahko zadostimo samo $60 \%$ potreb po OŠ učiteljih NARMATEH in le 40\% potreb po učiteljih TIT.

- $\quad$ Že pred letom 2020 bo začelo primanjkovati OŠ učiteljev TIT. Podobni trendi pa se kažejo tudi na celotnem področju izobraževanja NARMATEH.

- Nerešeni problemi, na katere so opozarjali udeleženci okrogle mize Stanje in razvoj tehničnega izobraževanja, 30. 6. 1997, se po 19 letih že odražajo v gospodarstvu.

Da bi preprečili zlom osnovnošolskega, srednješolskega in terciarnega izobraževanja TIT in NARMATEH, je potrebno ukrepati TAKOJ! Predlagane rešitve:

a) (že v letu 2017 razpisati) kadrovske štipendije za vzpodbujanje mladih za poklic učiteljev NARMATEH in še posebej učiteljev predmeta TIT;

b) financiranje študijskih programov za dokvalifikacijo in prekvalifikacijo za poučevanje tehnike;

c) zagotovitev financiranja ukrepov za povečanje promocije tehnike med mladimi;

d) zagotovitev ustreznih materialnih in kadrovskih pogojev na ustreznih Oddelkih $\mathrm{UM}$ in UL, ki bodo omogočili izvedbo programov $\mathrm{v}$ skladu $\mathrm{z}$ deklariranimi cilji izobraževanja za 21 stoletje. 
M. Ploj Virtič \& K. Dolenc: Poudarki

\section{Predlagane rešitve:}

a) (že v letu 2017 razpisati) kadrovske štipendije za vzpodbujanje mladih za poklic učiteljev NARMATEH in še posebej učiteljev predmeta TIT;

b) financiranje študijskih programov za dokvalifikacijo in prekvalifikacijo za poučevanje tehnike;

c) zagotovitev financiranja ukrepov za povečanje promocije tehnike med mladimi;

d) zagotovitev ustreznih materialnih in kadrovskih pogojev na ustreznih Oddelkih UM in UL, ki bodo omogočili izvedbo programov v skladu z deklariranimi cilji izobraževanja za 21 stoletje. 
VLOGA IN POMEN TEHNIŠKEGA IZOBRAŽEVANJA V OŠ: KDO BO POUČEVAL TEHNIKO LETA 2020?

\section{Pregled dosedanjih aktivnosti za reševanje problematike tehniškega izobraževanja}

O problematiki tehniškega izobraževanja se razpravlja že dobrih 20 let (Aberšek in drugi, 1997; Društvo za razvoj tehniškega izobraževanja, 2011; Posvet SAZU o poučevanju tehnike, 2012; Izzivi tehniškega izobraževanja v RS, 2016).

Začetek težav sega $\mathrm{v}$ konec 90 let prejšnjega stoletja, ko je bil oblikovan program devetletne OŠ. Na okrogli mizi z naslovom Stanje in razvoj tehničnega izobraževanja, 30. 6. 1997 so se zbrali kompetentni deležniki, ki so povzeli takratno stanje in postavili strategijo za nadaljnji kvalitetni razvoj tehniškega izobraževanja. Strategija je vključevala kratkoročni cilj:

- $\quad$ zagotoviti in motivirati študente $\mathrm{z}$ ustreznimi štipendijami

in naslednje dolgoročne cilje:

- enakomerna zastopanost strokovnjakov s tehniškega področja na nivojih odločanja (ministrstva, gospodarstvo),

- $\quad$ povečanje števila ur tehnike v OŠ (9.razred) in uvedba tehnike na splošnih gimnazijah,

- $\quad$ prikazati izobraževanje kot naložbo in ne strošek,

- $\quad$ sistemska promocija poklicev v OŠ,

- $\quad$ povečanje kakovosti tehniškega izobraževanja na vseh nivojih,

- celovito usposabljanje kakovostnih in kompetentnih učiteljev.

Nadalje se je kriza izobraževanja na terciarni stopnji močno poglobila z uvedbo bolonjskega študija in zatem še s finančno krizo, katere posledice so bile: varčevanje na račun kadrovske politike $\mathrm{v}$ javnem sektorju (učitelji, profesorji), uvedba Zakona za uravnoteženju javnih financ (ZUJF), pa tudi denarja za tehniške dejavnosti, ki razvijajo tehnološko pismenost mladih, je bilo v preteklih desetih letih bistveno manj.

Slovenska akademija znanosti in umetnosti (SAZU) je v sodelovanju z Društvom za razvoj tehniškega izobraževanja (DRTI) organizirala posvet o poučevanju tehnike (Posvet SAZU o poučevanju tehnike, 2012), na katerem so bile izpostavljene najbolj kritične točke. Takratna vlada RS je podprla prizadevanja deležnikov posveta in obljubila realizacijo zastavljenih ciljev, ki so bili:

- $\quad$ predmete s področja tehnike naj poučujejo le ustrezno usposobljeni učitelji,

- $\quad$ povečanje števila ur tehnike v OŠ (9.razred) in uvedba tehnike na splošnih gimnazijah, 
M. Ploj Virtič \& K. Dolenc: Pregled dosedanjih aktivnosti za reševanje problematike tehniškega izobraževanja

- finančno je potrebno spodbujati neformalne oblike tehniškega izobraževanja za generacijo od 12. do 18. leta,

- $\quad$ pri prenovi srednjega poklicnega in strokovnega izobraževanja (SPS) naj se v večji meri upoštevajo mnenja učiteljev strokovnih predmetov, gospodarstva in terciarnega izobraževanja,

- posodobitev sistema financiranja srednjega poklicnega in strokovnega izobraževanja (SPS),

- $\quad$ v sistemu stalnega strokovnega izpopolnjevanja učiteljev je potrebno razširiti ponudbo tehnoloških vsebin in vsebin trajnostnega razvoja, ki so povezane $\mathrm{z}$ različnimi tehnologijami,

- potrebna je ponovna uvedba štipendiranja pedagoškega študija na fakultetah,

- potrebno je sistematično razpisati večletne projekte, s katerimi bi za izobraževanje od osnovne šole do fakultetne ravni razvijali metodologijo tehniškega izobraževanja ter raziskovali, razvijali in vrednotili elemente tehnološke pismenosti oz. »tehnološke kompetence«.

Na najnovejšem posvetu o izzivih tehniškega izobraževanja v RS, ki ga je priredila Inženirska akademija Slovenije (IAS) 30. 6. 2016, so izpostavili problematiko iz vidika obrtnikov in gospodarstva (Izzivi tehniškega izobraževanja v RS, 2016).

Nerešeni problemi, na katere so opozarjali udeleženci okrogle mize Stanje in razvoj tehničnega izobraževanja, 30. 6. 1997, se po 19 letih že odražajo v gospodarstvu. Rešitve in predlogi, ki jih je na svojem posvetu podala IAS (2016) so enaki rešitvam in predlogom, kot so bili podani na Okrogli mizi Stanje in razvoj tehničnega izobraževanja (Aberšek in drugi, 1997) in posvetu SAZU (Posvet SAZU o poučevanju tehnike, 2012). 
VLOGA IN POMEN TEHNIŠKEGA IZOBRAŽEVANJA V OŠ: KDO BO POUČEVAL TEHNIKO LETA 2020?

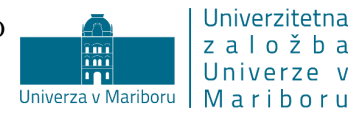

\section{Trenutno stanje tehniškega izobraževanja}

Formalno tehniško izobraževanje se prične v OŠ. Tam se postavijo temelji in razvije osnovna tehnološka pismenost posameznika, ki je ključna za razvoj interesov za nadaljnje tehniško izobraževanje. Raziskava tehnološke pismenosti med slovenskimi osnovnošolci (Šorgo in Ploj Virtič, 2016) je pokazala izjemno slabe rezultate. Avtorja sta med razlogi za slabe rezultate navedla tudi upad kakovosti tehniškega izobraževanja v OŠ. Eden od razlogov je bila zakonodaja, po kateri so smeli učitelji tudi do $40 \%$ svoje delovne obveze poučevati predmete, za katere niso imeli ustrezne izobrazbe. Nekateri indici kažejo na to, da je ravno predmet TIT poučevalo veliko učiteljev brez ustrezne usposobljenosti. Ta določba je na srečo v postopku ukinjanja, vendar bo za popravilo škode potrebno $\mathrm{v}$ šolah te učitelje nadomestiti z ustrezno kompetentnimi učitelji.

Ob reševanju nastale situacije se pojavi naslednje vprašanje:

\section{Ali imamo na voljo zadostno število kompetentnih učiteljev TIT?}

Z vsesplošnim upadom interesa za tehniške študije v zadnjih 10 letih, je upadel tudi interes za študij na področju izobraževanja učiteljev tehnike in tehnologije v OŠ.

Premalo ustrezno izobraženih učiteljev lahko v prihodnjih letih še dodatno poslabša tehnološko pismenost mladih. S tem smo v začaranem krogu brez izhoda.

$\mathrm{V}$ nadaljevanju je podrobneje predstavljeno številčno stanje učencev in učiteljev $\mathrm{V}$ osnovnih šolah ter stanje študentov (bodočih učiteljev) TIT. Za nadaljnjo analizo je potrebno spremljati tri ključne parametre:

- $\quad$ število prvošolcev v OŠ (graf 1),

- $\quad$ predvideno število upokojenih učiteljev v OŠ (graf 2) in

- $\quad$ število študentov, bodočih učiteljev TIT v OŠ (grafa 3 in 4).

Iz podatkov Statističnega urada RS (SURS) (graf 1) je razvidno, da se zadnjih 8 let povečuje število vpisov v 1. razred v OŠ. 
VLOGA IN POMEN TEHNIŠKEGA IZOBRAŽEVANJA V OŠ: KDO BO POUČEVAL TEHNIKO LETA 2020?

M. Ploj Virtič \& K. Dolenc: Trenutno stanje tehniškega izobraževanja

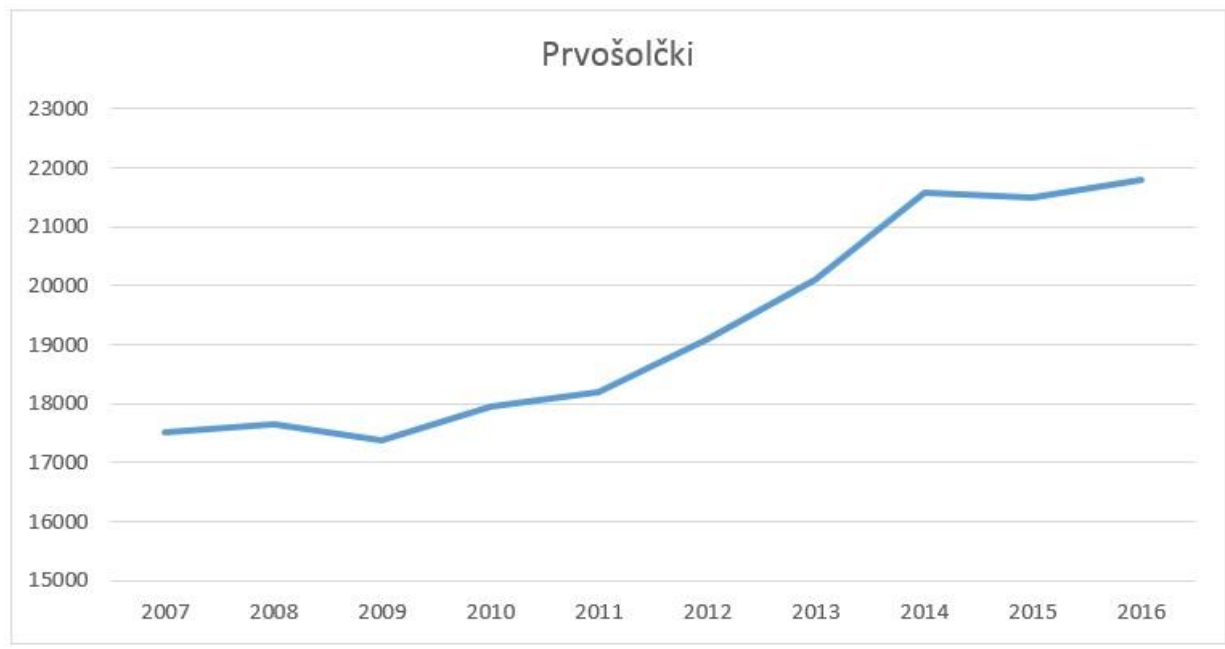

Graf 1 Vpis v prvi razred OŠ (vir: SURS)

Število učencev na predmetni stopnji, kjer se prične poučevanje TIT, se glede na število učencev v 1. razredu, povečuje s 6-letnim zamikom. To pomeni, da se bo prikazana rast števila učencev poznala na predmetni stopnji v naslednjih 6 letih. Posledica te rasti je večja potreba po novih učiteljih, tudi učiteljih TIT. Po drugi strani pa podatki MIZŠS kažejo pričakovano povečanje upokojenih učiteljev TIT v naslednjih 13 letih (graf 2).

\section{Upokojevanje od 2017 do 2056}

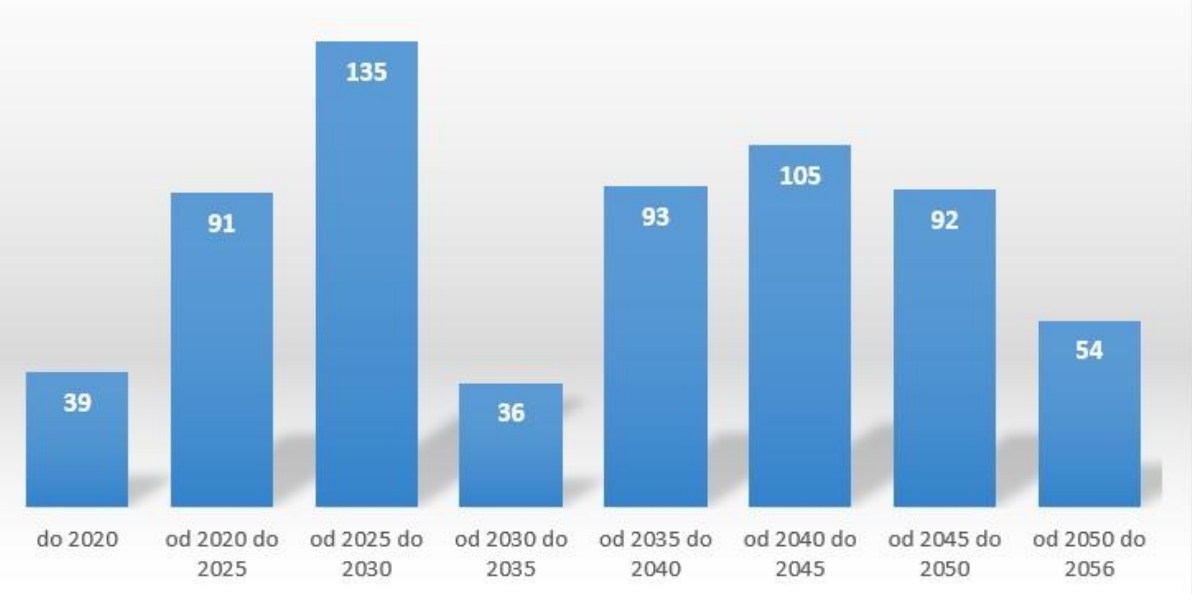

Graf 2 Predvideno upokojevanje učiteljev TIT v OŠ do leta 2056 
V projekciji upokojevanja MIZŠ je upoštevana idealna upokojitev (izpolnjevanje tako delovne dobe kot let) in niso upoštevani splošni dejavniki kot so npr. menjava službe, predčasna upokojitev, bolniške, porodniške itd..., kar še dodatno povečuje potrebo po učiteljih TIT.

Bodoče učitelje TIT izobražujeta dve fakulteti (FNM UM in PEF UL), kjer se soočajo z upadom vpisa (graf 3 ) ter posledično še večjim upadom diplomantov (graf 4).

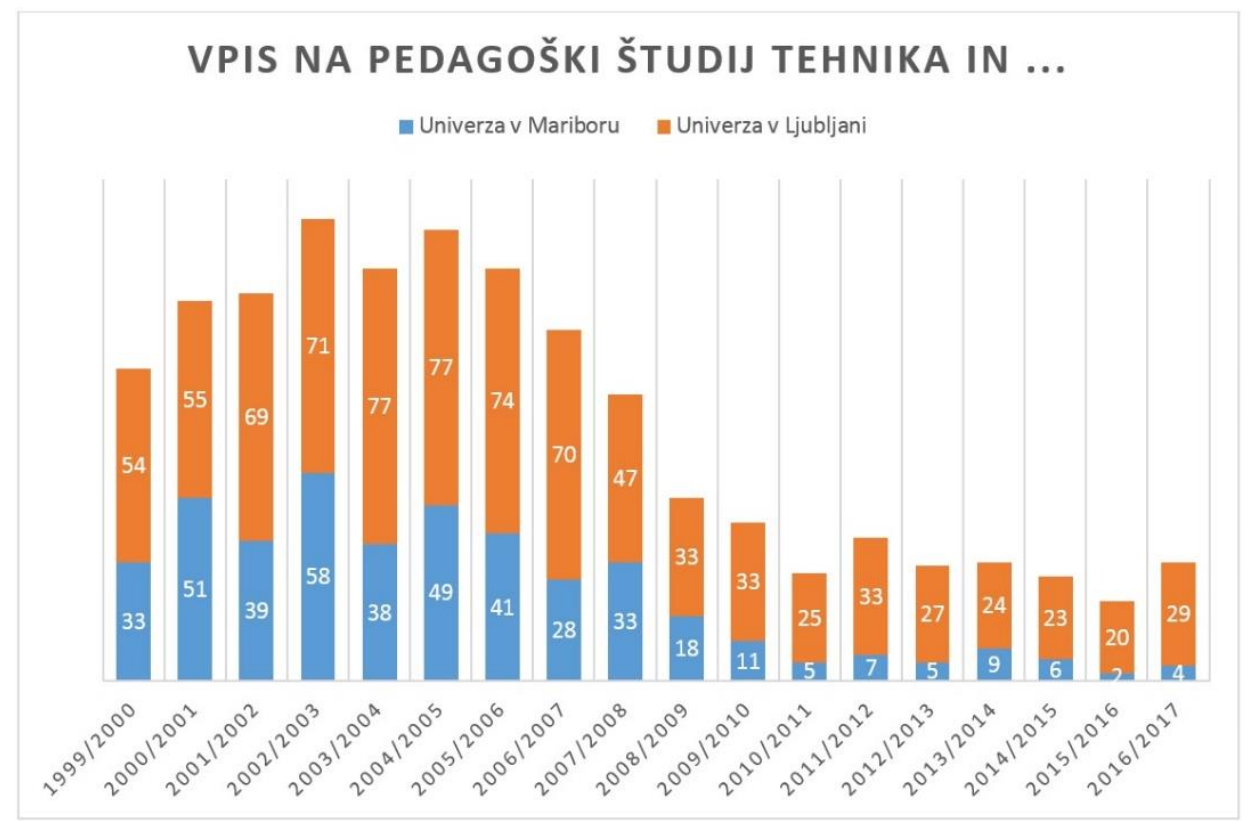

Graf 3 Vpis na fakulteti UM FNM in UL PeF

Iz analize vpisa na pedagoški študij tehnike je razvidno, da je po uvedbi bolonjskega modela visokošolskega študija in finančne krize, vpis padel kar za $70 \%$, diplomira oz. (bolonjsko) magistrira pa skupno le še 11 študentov pedagoške tehnike letno. Zaradi upada vpisa je $\mathrm{v}$ prihodnjih letih pričakovati še manjše število diplomantov. 
M. Ploj Virtič \& K. Dolenc: Trenutno stanje tehniškega izobraževanja

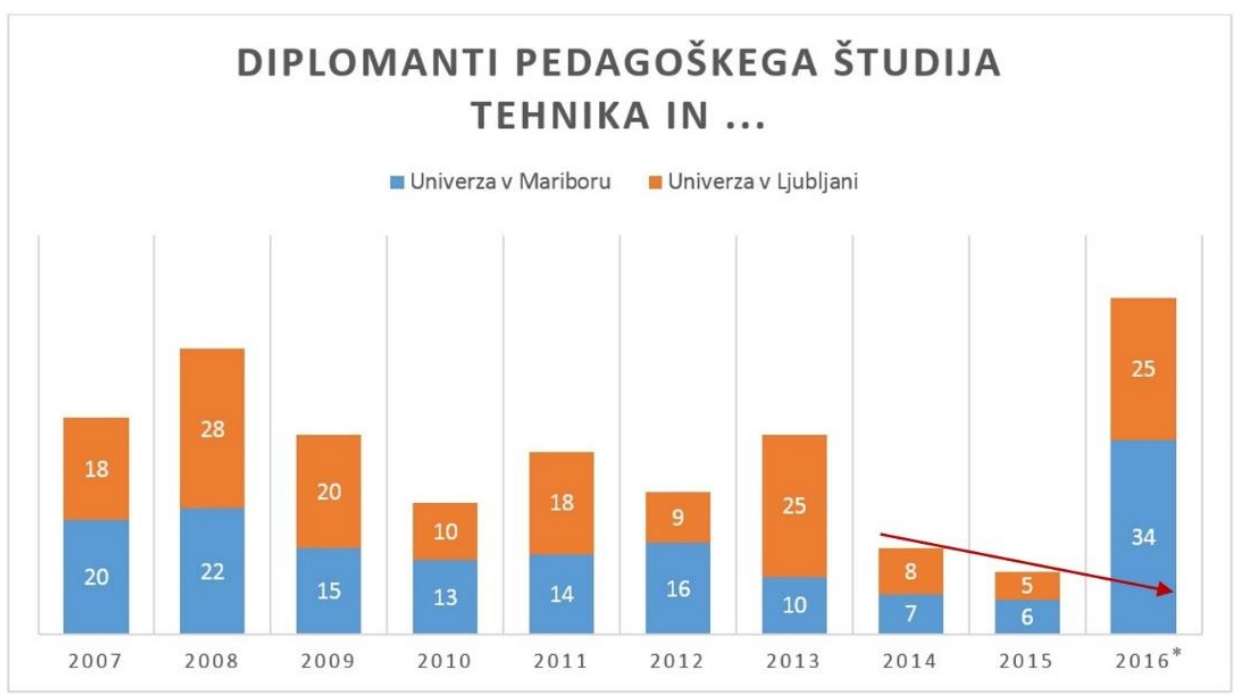

Graf 4 Diplomanti na fakulteti UM FNM in UL PF

*Opomba: Porast diplomantov leta 2016 se je zgodil zaradi izteka univerzitetnega (predbolonjskega) študija. Diplomanti so bili starejši in že zaposleni, kar je razvidno iz podatkov Zavoda RS za zaposlovanje (ZRSZ), kjer je registriranih le 8 iskalcev zaposlitve na delovno mesto učitelj TIT v OŠ.

Rdeča puščica na grafu označuje trend upada števila diplomantov, ki ga prepoznavamo iz trenutnega vpisa v programa UM in UL.

\section{Če povzamemo stanje:}

- Število prvošolcev v OŠ zadnjih 8 let narašča.

- Vpis in število diplomantov na študijski program pedagoške tehnike je od leta 2007 upadel za $70 \%$.

- Na leto diplomira le 11 študentov pedagoške tehnike in ta številka bo, glede na razpoložljive podatke o vpisu, v prihodnje še manjša. 
VLOGA IN POMEN TEHNIŠKEGA IZOBRAŽEVANJA V OŠ: KDO BO POUČEVAL TEHNIKO LETA 2020?

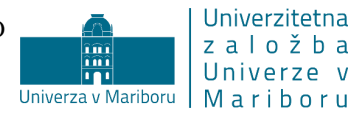

\section{Problematika tehniškega izobraževanja danes}

V osnovni šoli je pri predmetu TIT potrebno poskrbeti za kompetentne učitelje, ki bodo sposobni vsebine predmeta TIT prilagajati hitremu razvoju različnih tehnologij. Skrb za kompetentne učitelje TIT je torej na prvem mestu! Pomanjkanje ustrezno izobraženih učiteljev je prepoznano tudi kot svetovni problem, ki še posebej pesti države v razvoju.

Do sedaj kriza pomanjkanja ustrezno izobraženih učiteljev v Sloveniji ni bila tako očitna zaradi sovpadanja nekaterih kratkoročnih trendov:

- $\quad$ Prvi trend je bilo pogosto nadomeščanje upokojenih učiteljev TIT z učitelji brez ustrezne izobrazbe, kar je dovoljevala naša zakonodaja in predstavlja neposredno »kršitev« 13. člena priporočil UNESCA. Ukrep je sicer v fazi odpravljanja, bo pa zaradi zahtev po zaposlovanju ustreznega kadra, še dodatno poglobil krizo pomanjkanja ustrezno izobraženih učiteljev.

- Drugi trend je bil nedvomno upad števila učencev v posamezni generaciji, ki pa se je zaustavil, in število učencev ponovno narašča. Posledično je bilo zaposlenih manj mladih učiteljev, kjer pa je prihajalo do presežkov ur, so si jih med seboj porazdelili obstoječi učitelji ene ali več šol.

- Tretji trend je podaljševanje delovne dobe za ženske, ki prevladujejo v učiteljskem poklicu.

Navedeni trendi so za nekaj let prikrili dejansko krizo, njihove posledice pa bodo močno opazne čez 4 leta, kot je prikazano v nadaljevanju.

Da je kriza le prikrita, oz. ni dovolj poudarjena, prikazujemo s kombiniranjem javno dostopnih podatkov, kot so število diplomantov ustreznih pedagoških izobraževalnih smeri, številom iskalcev zaposlitev in predvidenim upokojevanjem učiteljev.

$\mathrm{V}$ ta namen smo maja 2016 na MIZŠ posredovali prošnjo za kratko, srednje in dolgoročno kadrovsko projekcijo upokojevanja učiteljev NARMATEH v OŠ. Pridobili smo tudi podatke ZRSZ o učiteljih TIT v OŠ, ki so prijavljeni na zavod kot iskalci zaposlitve. Hkrati smo preverili, kako se giblje število diplomantov na FNM UM in PeF UL ter ob tem dobili alarmantne rezultate. Rezultati za področje TIT so prikazani $v$ grafu 5 . 
M. Ploj Virtič \& K. Dolenc: Problematika tehniškega izobraževanja danes

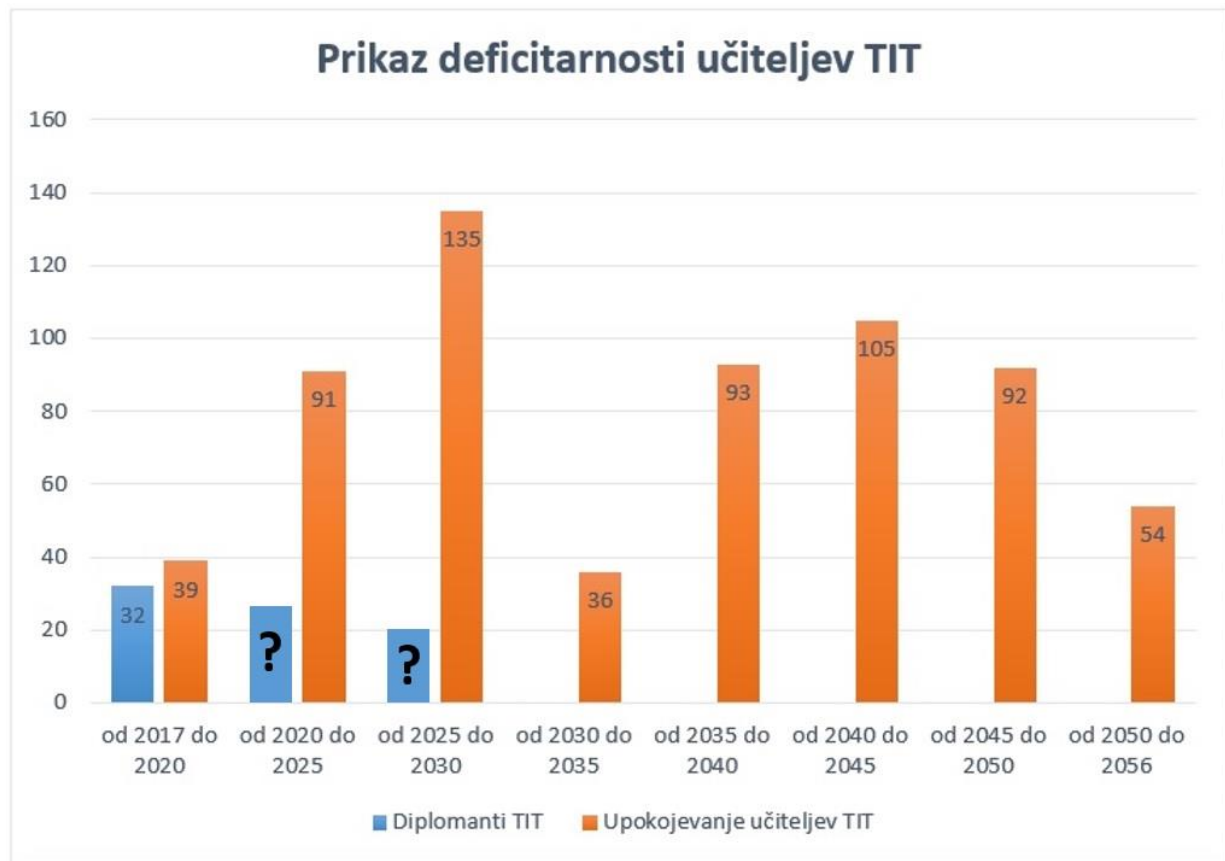

Graf 5 Gibanje upokojitev učiteljev TIT in diplomantov TIT

Iz projekcije diplomantov obeh fakultet in zgolj projekcije upokojevanja lahko sklenemo naslednje potrebe po kandidatih za študij pedagoške tehnike:

1. Kratkoročne potrebe $(2017$ - 2020) po učiteljih TIT so približno 10 učiteljev letno. Glede na regijsko porazdelitev to pomeni, da jih mora vsaka od fakultet izobraziti približno polovico, torej 5 letno. Po podatkih, s katerimi razpolagamo, bo za naslednja 4 leta to število novih učiteljev TIT v idealnih* pogojih komaj ustrezalo zadostiti potrebam upokojevanja.

2. Srednjeročne potrebe $(2020-2030)$ po učiteljih bodo po podatkih MIZŠ več kot 3 x višje! V navedenem desetletnem obdobju bo slovensko šolstvo potrebovalo kar 24 novih učiteljev TIT letno samo za pokrivanje upokojitev. Zaradi regijske razpršenosti mora biti izvedba študijskega programa locirana na dveh mestih (izhajamo iz izkušenj na poklicnem področju zdravnikov, kjer so velike težave s kadri v ruralnih območjih). Študenti, ki so vpisani v letu 2016/2017 v prvi letnik, bodo predvidoma zaključili svoj študij leta 2021/2022. Gre za prvo generacijo, ki je že del srednjeročnega kadrovskega načrta. Dijaki, ki se bodo vpisovali na omenjeni študij v naslednjih 10 letih, bodo glede na trenutni interes za študij zagotovo dobili prosto delovno mesto. 
M. Ploj Virtič \& K. Dolenc: Problematika tehniškega izobraževanja danes

* Idealni pogoji predvidevajo, da bi se vsi diplomanti zaposlili kot učitelji TIT v OŠ. V praksi se nekateri zaposlijo bodisi v SŠ, bodisi izven šolstva.

3. Dolgoročne potrebe $(2030$ - 2054) po učiteljih TIT po naših podatkih nekoliko zanihajo (graf 5) in se ponovno povečajo. Dolgoročno načrtovanje lahko predstavlja okvirni trend, ki ga je potrebno spremljati in se mu prilagajati.

Če povežemo vse navedene informacije, dobimo alarmantne rezultate:

- V naslednjih 13 letih (2017-2030) se bo upokojilo 265 učiteljev TIT, (vir: Ministrstvo za izobraževanje, znanost in šport (MIZŠ));

- vpis in število diplomantov na študijskih programih pedagoške tehnike je od leta 2007 upadel za 70\% (manj kot 10 letno);

- $\quad$ s trenutnim številom diplomantov Univerz v Mariboru (UM) in Ljubljani (UL) lahko zadostimo samo $\mathbf{4 0} \%$ potreb po učiteljih TIT;

- $\quad$ že pred letom 2020 bo začelo primanjkovati OŠ učiteljev TIT.

Ob dobljenih rezultatih se upravičeno sprašujemo, kdo bo po letu 2020 v OŠ učil TIT? In kakšne dodatne posledice bo to prineslo slovenskemu gospodarstvu?

Leta 1997 je v povzetku prispevkov okrogle mize Stanje in razvoj tehniškega izobraževanja ddr. Aberšek napisal (Aberšek in drugi, 1997):

»Ni potrebno posebej poudarjati, da je naše gospodarstvo v krizi že vrsto let. To je isto gospodarstvo, ki je pred tem bilo uspešno, celo v nekaterih segmentih zelo uspešno. Res je, da se je v tem času marsikaj zgodilo, da smo morali vsi spremeniti naša razmišljanja, tako rekoč čez noč, da smo izgubili določene trge in da se je način trgovanja bistveno spremenil. Ugotavljam lahko le, da smo bili za te spremembe tako rekoč slabo pripravljeni, oz. skoraj nepripravljeni. Tako, kot je bilo slabo pripravljeno naše gospodarstvo, je bil slabo pripravljen celoten državni sistem, vključno šolstvo. Zavedati se moramo, da se vse prične v šoli. Tu se pričnejo kaliti kadri, ki bodo $v$ prihodnosti nosilci našega razvoja. Če bo ta »kalilnica« dobra, potem se nam prihodnosti ni potrebno bati. Če pa ne...?«

Leta 2016 lahko ponovimo zgornji zapis in mu dodamo drugačen zaključek:

»Kalilnica žal ni bila zadostna, v 19 letih se na področju tehniškega izobraževanja ni spremenilo veliko. Zato bo tokrat potrebno improvizirati. Kako se bomo znašli v zlomu izobraževalnega sistema? « 

VLOGA IN POMEN TEHNIŠKEGA IZOBRAŽEVANJA V OŠ: KDO BO POUČEVAL TEHNIKO LETA 2020?

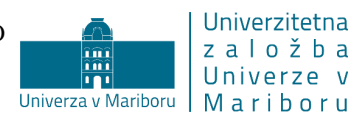

\section{Predlagani ukrepi}

Na podlagi opravljene analize je za zagotovitev zadostnega števila učiteljev TIT potrebno TAKOJ izvesti naslednje ukrepe:

a) (že v letu 2017 razpisati) ustrezno število kadrovskih štipendij za vzpodbujanje mladih za poklic učiteljev TIT;

b) financiranje študijskih programov za dokvalifikacijo in prekvalifikacijo za poučevanje tehnike (npr.: Študijski program enopredmetne Izobraževalne tehnike Fakultete za naravoslovje in matematiko Univerze v Mariboru (FNM UM) in Študijski program za izpopolnjevanje iz tehnike in tehnologije Pedagoške fakultete Univerze v Ljubljani (PeF UL));

c) zagotovitev financiranja ukrepov za povečanje promocije tehnike med mladimi;

d) zagotovitev ustreznih materialnih in kadrovskih pogojev na ustreznih Oddelkih UM in UL, ki bodo omogočili izvedbo programov v skladu z deklariranimi cilji izobraževanja za 21 stoletje.

Navedeni ukrepi so NUJNI za normalno delovanje šolskega sistema, saj analiza podatkov kaže, da bo potreba po mladih učiteljih TIT bistveno večja že za generacijo, ki se vpisuje letos!

Poleg nujnih ukrepov za vzdržno delovanje šolskega sistema je potrebno upoštevati tudi potrebe gospodarstva, za katere ni dovolj zgolj kvantiteta, temveč upravičeno zahtevajo tudi kvaliteto.

Za zagotovitev kakovostnega tehniškega izobraževanja pa je poleg nujnih ukrepov potrebno upoštevati in realizirati še nasvete, ki so jih deležniki podajali v preteklih 20 letih:

- $\quad$ povečanje števila ur tehnike v OŠ (9.razred) in uvedba tehnike na splošnih gimnazijah,

- $\quad$ finančno je potrebno spodbujati neformalne oblike tehniškega izobraževanja za generacijo od 12. do 18. leta,

- $\quad$ pri prenovi srednjega poklicnega in strokovnega izobraževanja (SPS) naj se v večji meri upoštevajo mnenja učiteljev strokovnih predmetov, gospodarstva in terciarnega izobraževanja,

- posodobitev sistema financiranja srednjega poklicnega in strokovnega izobraževanja (SPS), 
14 VlOGA IN POMEN TEHNIŠKEGA IZOBRAŽEVANJA V OŠ: KDO BO POUČEVAL TEHNIKO LETA 2020?

M. Ploj Virtič \& K. Dolenc: Predlagani ukrepi

- $\quad$ v sistemu stalnega strokovnega izpopolnjevanja učiteljev je potrebno razširiti ponudbo tehnoloških vsebin in vsebin trajnostnega razvoja, ki so povezane $\mathrm{z}$ različnimi tehnologijami,

- potrebno je sistematično razpisati večletne projekte, s katerimi bi za izobraževanje od osnovne šole do fakultetne ravni razvijali metodologijo tehniškega izobraževanja ter raziskovali, razvijali in vrednotili elemente tehnološke pismenosti oz. »tehnološke kompetence«. 
VLOGA IN POMEN TEHNIŠKEGA IZOBRAŽEVANJA V OŠ: KDO BO POUČEVAL TEHNIKO LETA 2020?

M. Ploj Virtič \& K. Dolenc

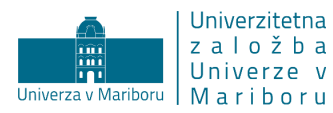

\section{Problematika NARMATEH izobraževanja danes}

Podobni trendi, kot na področju TIT, se kažejo tudi na področju NARMATEH (graf 6).

Če nanizamo samo nekaj podatkov:

- V naslednjih 13 letih (2017-2030) se bo upokojilo 1236 OŠ učiteljev NARMATEH.

- Vpis in število diplomantov na pedagoške programe NARMATEH je od leta 2007 upadel za $60 \%$.

- $\quad$ Na leto diplomira le še 69 bodočih OŠ učiteljev NARMATEH, ta številka pa še pada.

- $\quad \mathrm{S}$ trenutnim vpisom in številom diplomantov (UM in UL) lahko zadostimo samo $50 \%$ potreb po OŠ učiteljih NARMATEH.

- $\quad$ Že pred letom 2020 bo začelo primanjkovati učiteljev NARMATEH v OŠ.

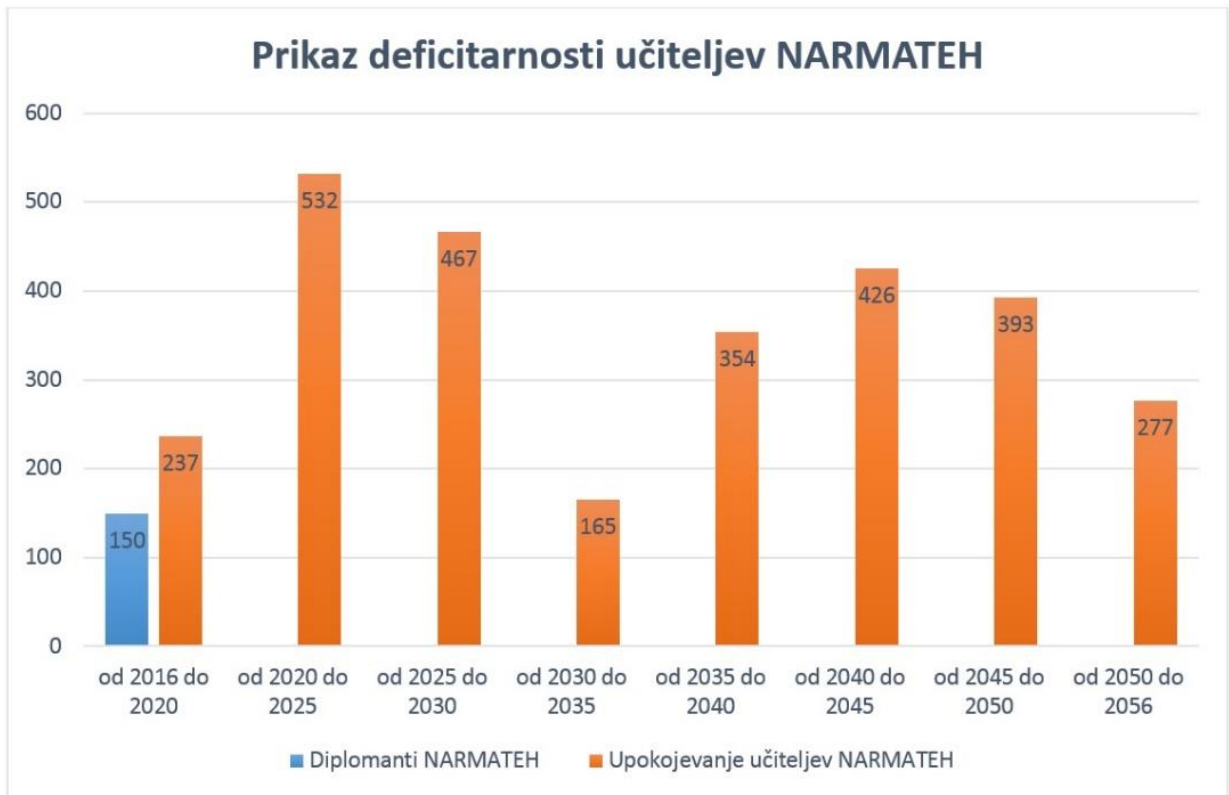

Graf 6 Gibanje upokojitev učiteljev NARMATEH in diplomantov NARMATEH 
16 VlOGA IN POMEN TEHNIŠKEGA IZOBRAŽEVANJA V OŠ: KDO BO POUČEVAL TEHNIKO LETA 2020 ?

M. Ploj Virtič \& K. Dolenc: Problematika NARMATEH izobraževanja danes

Opomba: Rdeča puščica na grafu označuje trend upada števila diplomantov NARMATEH, ki ga prepoznavamo iz trenutnega vpisa v programe UM in UL in interesa za te študije med mladimi.

Ob dobljeni primerjavi pa se lahko le vprašamo, kdo bo leta 2020 sploh še učil NARMATEH v OŠ? 
VLOGA IN POMEN TEHNIŠKEGA IZOBRAŽEVANJA V OŠ: KDO BO POUČEVAL TEHNIKO LETA 2020?

M. Ploj Virtič \& K. Dolenc

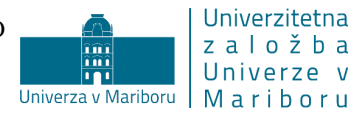

\section{Literatura}

Aberšek, B. in drugi (1997). Stanje in razvoj tehničnega izobraževanja. Pedagoška fakulteta, Maribor.

Društvo za razvoj tehniškega izobraževanja (2011). Ocena stanja tehniškega izobraževanja v Sloveniji in predlogi za izboljšanje (Report). Ljubljana: Society for the Development of Technology Education. Pridobljeno 29.11.2016, na povezavi: http://www.drti.si/docs/StanjeTeh.pdf.

Izzivi tehniškega izobraževanja v RS (2016). Pridobljeno 29.11.2016, na povezavi: http://www.ias.si/data/upload/1_tematski_vecer_Tehnisko_izobrazevanje_v_osnovnih__sre dnjih_in_visjih_solah.pdf.

Slovenska akademija znanosti in umetnosti (2012). Posvet SAZU o poučevanju tehnike. Pridobljeno 29.11.2016, na povezavi: http://vpo.sazu.vpo.si/simages/447-34-3.pdf.

Šorgo, A. in Ploj Virtič, M. (2015). Can we expect to recruit future engineers among students who have never repaired a toy?. Eurasia Journal of Mathematics, Science and Technology Education, 12(2), 249-266.

Baza podatkov o vpisih in diplomantih 2007 do 2016 FNM UM.

Baza podatkov o vpisih in diplomantih 1999 do 2007 PeF UM.

Baza podatkov o vpisih in diplomantih 1999 do 2016 PeF UL.

Statistični urad RS.

Zavod RS za zaposlovanje. 

VLOGA IN POMEN TEHNIŠKEGA IZOBRAŽEVANJA V OŠ: KDO BO POUČEVAL TEHNIKO LETA 2020?

M. Ploj Virtič \& K. Dolenc

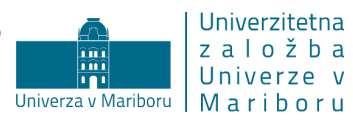

\section{Priloga: Statistični podatki vpisa in diplomantov}

\section{Univerza v Mariboru, Fakulteta za naravoslovje in matematiko}

Vpis na dvopredmetne pedagoške programe po smereh:

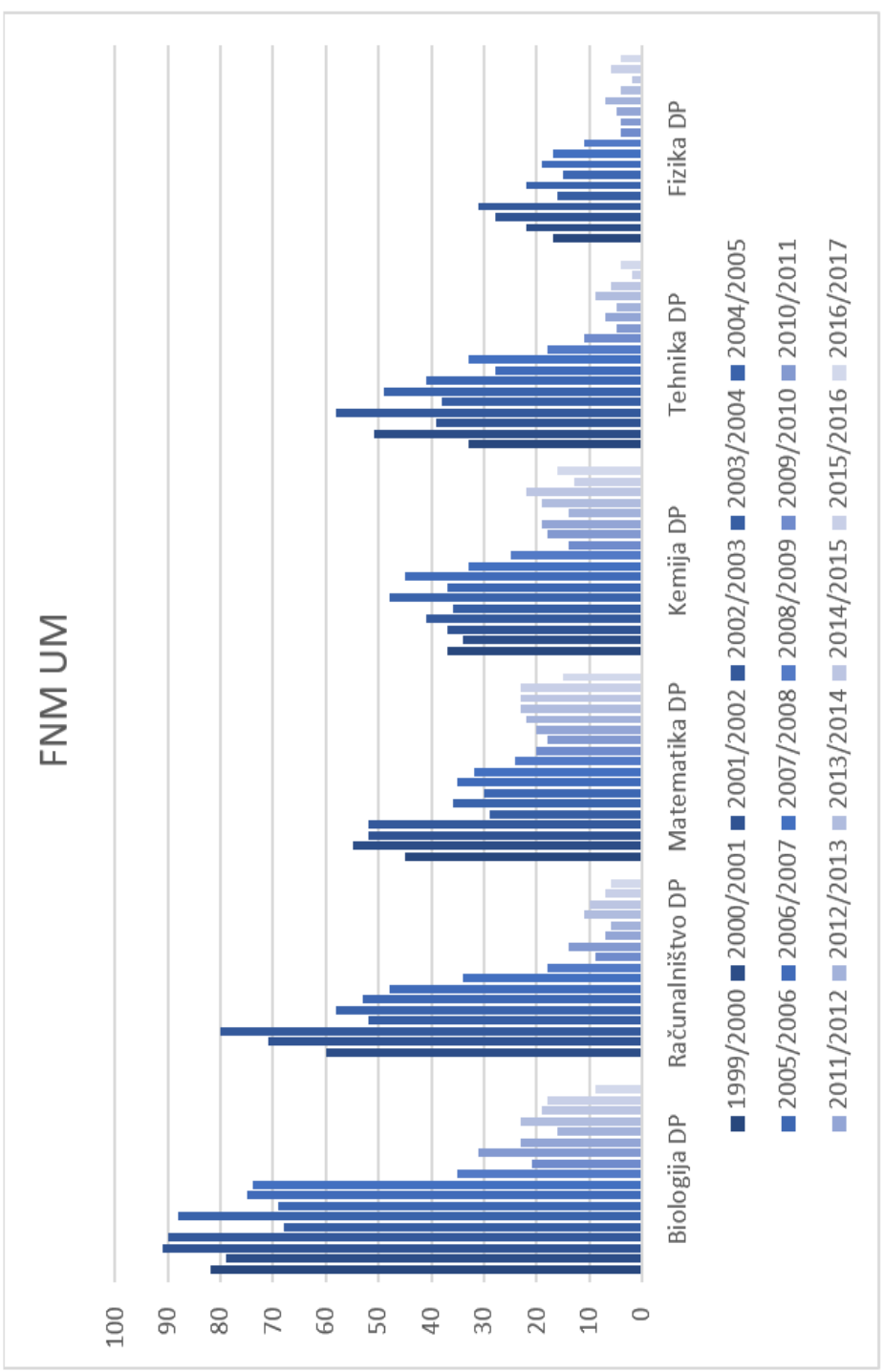


VLOGA IN POMEN TEHNIŠKEGA IZOBRAŽEVANJA V OŠ: KDO BO POUČEVAL TEHNIKO LETA 2020?

M. Ploj Virtič \& K. Dolenc: Priloga: Statistični podatki vpisa in diplomantov

Diplomanti dvopredmetnih pedagoških programov po smereh:

\begin{tabular}{|c|c|c|c|c|c|c|c|c|}
\hline \multirow[b]{2}{*}{2003} & Fizika DP & Biologija DP & \multicolumn{2}{|c|}{ Kemija DP } & Računalništvo DP & \multicolumn{3}{|c|}{ DP Tehnika DP *št. diplomantov } \\
\hline & 分 & $14 \Rightarrow$ & $20 \Rightarrow$ & 16 & $\Rightarrow$ & $17 \sqrt{b}$ & $15 \Rightarrow$ & 41 \\
\hline 2004 & $\Rightarrow$ & 9 令 & 24 令 & 19 & $\Rightarrow$ & $24 \Rightarrow$ & $17 \Rightarrow$ & 46,5 \\
\hline 2005 & ↔ & $11 \Rightarrow$ & 22 个 & 21 & $1 \Rightarrow$ & $19 \sqrt{6}$ & $11 \Rightarrow$ & 42,5 \\
\hline 2006 & $\Rightarrow$ & 6 命 & $24 \Rightarrow$ & 16 & $5 \Rightarrow$ & $18 \sqrt{b}$ & $13 \Rightarrow$ & 41 \\
\hline 2007 & $\Rightarrow$ & 9 ค & 27 ค & 18 & $13 \Rightarrow$ & $17 \Rightarrow$ & $20 \Rightarrow$ & 52 \\
\hline 2008 & 公 & $10 \Rightarrow$ & $23 \Rightarrow$ & 14 & 8 ก & $27 \Rightarrow$ & $22 \Rightarrow$ & 52 \\
\hline 2009 & $\Rightarrow$ & 7 用 & 26 令 & 17 & $11 \Rightarrow$ & $21 \sqrt{6}$ & $15 \Rightarrow$ & 48,5 \\
\hline 2010 & $\Rightarrow$ & $6 \Rightarrow$ & 22 ค & 23 & $8 \Rightarrow$ & $15 \sqrt{3}$ & $13 \Rightarrow$ & 43,5 \\
\hline 2011 & $\Rightarrow$ & 7 ค & $26 \Rightarrow$ & 15 & 10 令 & $29 \sqrt{6}$ & $14 \Rightarrow$ & 50,5 \\
\hline 2012 & 尔 & $11 \Rightarrow$ & $21 \Rightarrow$ & 15 & $9 \Rightarrow$ & $19 \Rightarrow$ & $16 \Rightarrow$ & 45,5 \\
\hline 2013 & $\Rightarrow$ & $8 \sqrt{3}$ & $15 \Rightarrow$ & 13 & $9 \sqrt{6}$ & $11 \sqrt{6}$ & $10 \sqrt{3}$ & 33 \\
\hline 2014 & $\sqrt{3}$ & $2 \sqrt{3}$ & 18 & 9 & $2 \sqrt{3}$ & $6 \sqrt{3}$ & $7 \sqrt{3}$ & 22 \\
\hline 2015 & $\sqrt{3}$ & $1 \sqrt{y}$ & $15 \sqrt{b}$ & 4 & $5 \sqrt{b}$ & $9 \sqrt{4}$ & $6 \sqrt{6}$ & 20 \\
\hline 2016 & 成 & 14 กิ & 43 命 & 22 & 16 令 & 33 命 & 34 个 & 81 \\
\hline
\end{tabular}

* št. diplomantov je deljeno z 2 zaradi vezav $v$ dvopredmetnem študiju. Vsaka smer je polovica študijskega programa. $V$ primerih, kjer so vezave študijskega programa $z$ drugimi fakultetami (npr. tehnika in filozofija), je v vsoti prikazano le 0,5 študenta (npr, 0,5 je prikazano na Filozofski fakulteti).

Povečano število diplomantov je posledica masovnega zaključevanja predbolonjskih diplom. Ti diplomanti so že zaposleni, kot je razbrati iz podatkov o številu iskalcev zaposlitve na ZRSZZ. Trend števila diplomantov sicer pada, kot je razvidno iz trenutnega vpisa na študijske programe. 
M. Ploj Virtič \& K. Dolenc: Priloga: Statistični podatki vpisa in diplomantov

\section{Univerza v Ljubljani, Pedagoška fakulteta}

Vpis na dvopredmetne pedagoške programe:

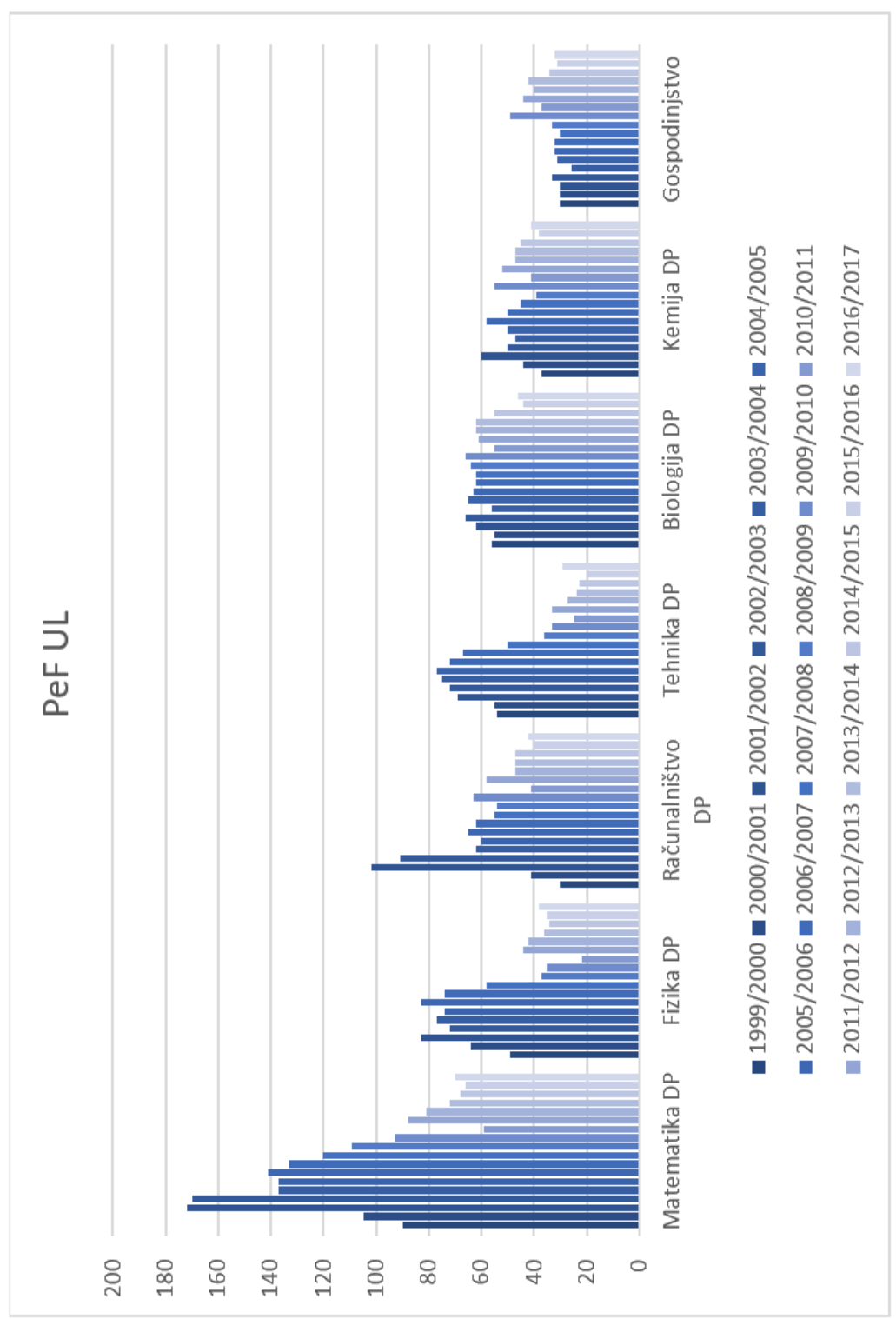


VLOGA IN POMEN TEHNIŠKEGA IZOBRAŽEVANJA V OŠ: KDO BO POUČEVAL TEHNIKO LETA 2020 ?

M. Ploj Virtič \& K. Dolenc: Priloga: Statistični podatki vpisa in diplomantov

Diplomanti dvopredmetnih pedagoških programov po smereh:

\begin{tabular}{|c|c|c|c|c|c|c|c|c|c|c|}
\hline & Fizik & & Biologija DP & Kem & $\mathrm{Ra}$ & lačunalništvo DP & Gospodinjstvo & Matematika DP & Tehnika DP & *Št. diplomantov \\
\hline 2007 & $\Rightarrow$ & $21 \Rightarrow$ & $\Rightarrow \quad 37$ & $\xi$ & 20 ↔ & 22 & 19 & $\Rightarrow \quad 42$ & $\Rightarrow \quad 18$ छ & $\Rightarrow \quad 89,5$ \\
\hline 2008 & 令 & $30 \Rightarrow$ & 36 & & 20 令 & 22 & 21 & 57 & 28 令 & 107 \\
\hline 2009 & ^ & $23 \Rightarrow$ & 41 & ह) & 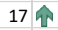 & 26 & 27 & 50 & $20 \Rightarrow$ & 102 \\
\hline 2010 & $\Rightarrow$ & $15 \Rightarrow$ & 40 & $\xi$ & $22 \Rightarrow$ & 18 & 21 & 32 & 10 하 & 79 \\
\hline 2011 & $\sqrt{4}$ & $12 \sqrt{4}$ & 26 & $\sqrt{4}$ & 11 令 & 23 & 17 & 41 & 18 & 74 \\
\hline 2012 & 令 & $22 \sqrt{4}$ & 34 & $\xi$ & 19 令 & 21 & 15 & 44 & $9 \Rightarrow$ & 82 \\
\hline 2013 & 令 & 22 คิ & 54 & 令 & 24 令 & 20 & 22 & 50 & 25 令 & 108,5 \\
\hline 2014 & $\sqrt{4}$ & $12 \Rightarrow$ & 35 & 4 & $14 \sqrt{3}$ & 3 & 22 & 18 & 8 & 56 \\
\hline 2015 & 4 & $4 \sqrt{4}$ & 25 & $y$ & $11 \Rightarrow$ & 15 & 14 & 24 & $5 \sqrt{3}$ & 49 \\
\hline 2016 & ه & 27 ค & 68 & 令 & $28 \Rightarrow$ & 16 & 43 & 52 & 25 ↔ & 129,5 \\
\hline
\end{tabular}

* št. diplomantov je deljeno z 2 zaradi vezav $v$ dvopredmetnem študiju. Vsaka smer je polovica študijskega programa.

Povečano število diplomantov je posledica masovnega zaključevanja predbolonjskih diplom. Ti diplomanti so že zaposleni, kot je razbrati iz podatkov o številu iskalcev zaposlitve na ZRSZZ. Trend števila diplomantov sicer pada, kot je razvidno iz trenutnega vpisa na študijske programe. 